\title{
AOR
}

Selected Papers of \#AoIR2021:

The 22nd Annual Conference of the

Association of Internet Researchers

Virtual Event / 13-16 Oct 2021

\section{DIESEL DEATH ZONES IN THE AMAZON EMPIRE: ENVIRONMENTAL JUSTICE AND ALGORITHMICALLY MEDIATED WORK}

\author{
Sonja Solomun* \\ McGill University \\ Rachel Bergmann* \\ Microsoft Research New England \\ ${ }^{*}$ co-first authors
}

\section{Introduction}

In 2019 Amazon announced a Climate Pledge to be net zero carbon by 2040; a few months later, their CEO Jeff Bezos announced a 10 billion dollar "Earth Fund" to fund climate research. Other tech companies like Google, Microsoft, and Netflix have made similar commitments to fund climate research and achieve "net zero."

As a trillion-dollar digital platform company, Amazon provides a considerable portion of the infrastructure that supports internet technologies (Alimohamed-Wilson \& Reese, 2020). At the same time, "Big Tech" has come under mounting public and policy scrutiny for the extractive business models of "platform capitalism" (Srnick, 2017) and their impacts on tech workers (e.g., Roose, 2018; Dubal, 2020). Yet environmental justice remains largely siloed from these important interventions.

In December 2019—just after Amazon's Climate Pledge announcement-a coalition of residents and community groups in Southern California called the San Bernardino Airport Communities (SBAC) organized a Cyber Monday community picket line at one of Amazon's 16 facilities in the Inland Empire. This group was focused particularly on the intersections of worker rights and environmental justice.

This paper examines who and what is left out when conversations around technology and sustainability are limited to global, multi-million-dollar "climate funds" and abstract measures like carbon neutrality. We ask: What would it look like to consider the technology industry's role in climate change by centering the perspectives of those who currently experience these environmental harms? The vast networks of warehouses, trucks, highways, airports, railways, and logistics hubs that constitute the infrastructure

Suggested Citation (APA): Solomun, S. ${ }^{*}$ \& Bergmann, R. ${ }^{*}$ (2021, October). Diesel Death Zones in the Amazon Empire: Environmental Justice and Algorithmically Mediated Work. Paper presented at AoIR 2021: The 22nd Annual Conference of the Association of Internet Researchers. Virtual Event: AolR.

Retrieved from http://spir.aoir.org. 
behind our platform ecosystems have significant environmental consequences for the neighbors and communities that physically surround them (Parks \& Starosielski 2015; Crawford, 2021). In the US, environmental and economic exploitation often intersect: these are often the same communities of low-power, low-wage, racialized workers, including gig workers, warehouse workers, and "the many janitors, cafeteria staff, security officers, and other contract workers who power tech" (Kneese, n.d.). This case study demonstrates that far from being independent struggles, the fights for tech worker rights and environmental justice are instead deeply intertwined. Further analysis on both platform labor and on the environmental impacts of algorithmic systems must therefore consider them as such.

\section{Methods}

Informed by "ecologically informed intersectionality" (Tuana, 2019), we use this case study to explore how geographic place, environment, race, migrant status, and worker status are interrelated categories of power relations that mutually shape one another. We use an environmental justice framework that emphasizes the relational dimension of climate justice and, in particular, attachment to place (Schlosberg, Rickards, and Byrne, 2017). Conceptualizing platform infrastructure through this lens enables us to extend "green technology" discussions beyond carbon footprint and instead centre interdependence - the relationships and places that surround, support, and are harmed by these systems.

We analyzed campaign materials and local and national coverage of the SBAC Eastgate / Amazon Air campaign alongside primary materials from Amazon about their climate pledges. We additionally drew from general and campaign documentation from the local community organizations who formed the SBAC coalition. This case situates questions of tech justice in a specific place and moment in time and provides an opportunity to analyze the ways platform technologies affect communities "on the ground."

\section{Findings}

SBAC argued that Amazon, already the largest employer in the area, would enact environmental racism with their new air cargo hub in the predominantly Hispanic, working-class Riverside and San Bernardino counties (Amazon Employees for Climate Justice, 2020). The hub's increased plane and diesel truck traffic would worsen California's "diesel death zones," a term activists aptly use for the premature deaths and respiratory diseases and cancers caused by dangerous amounts of diesel exhaust near highways.

The SBAC coalition used a wide range of organizing tactics in their Eastgate campaign, a reflection of place-specific histories of labor and environmentalism as well as the diversity of groups the coalition brought together (Sarathy, 2013). SBAC's central demand for "good jobs, healthy communities" points to a dual crisis faced by the communities in and around San Bernardino: environmental exploitation and un- and underemployment (Morello-Frosch et al., 2001; Allison et al., 2018). Although warehouses like Eastgate bring new jobs, many are temporary, unreliable, or

Suggested Citation (APA): Solomun, S. ${ }^{*}$ \& Bergmann, R. ${ }^{*}$ (2021, October). Diesel Death Zones in the Amazon Empire: Environmental Justice and Algorithmically Mediated Work. Paper presented at AoIR 2021: The 22nd Annual Conference of the Association of Internet Researchers. Virtual Event: AolR. Retrieved from http://spir.aoir.org. 
contingent; do not pay livable wages; do not include benefits; are heavily surveilled; and include inadequate workplace safety measures.

Importantly, SBAC was not organizing to push Amazon out of San Bernardino altogether. Instead, SBAC demanded a Community Benefits Agreement (CBA) with Amazon and the real estate developer, which would include legally enforceable measures to improve the community. An agreement like this would help address the labor and environmental crises of San Bernardino and link economic development with improving quality of life for the community, not just profit for the developers and their tenants.

\section{Conclusion}

This case study illustrates one way that commitments to environmental justice and economic justice can be aligned in platform studies if workers and community are centered, rather than abstracted in discussions of global technological governance and sustainability. By using a relational environmental justice framework, attachment to place becomes a central analytic for understanding how tech workers and their agency are deeply entangled within contexts that include their homes, schools, geographies, communities, and the air they breathe. This case demonstrates the need to center the environment in tech work, and to center the worker in sustainable technology, in order to work towards an ethics of mutuality that prioritizes interdependence, solidarity, and shared responsibility.

\section{References}

Alimahomed-Wilson, J., \& Reese, E. (Eds.). (2020). The Cost of Free Shipping: Amazon in the Global Economy. Pluto Press.

Allison, J. E., Herrera, J. S., Struna, J., \& Reese, E. (2018). The matrix of exploitation and temporary employment: Earnings inequality among Inland Southern California's blue-collar warehouse workers. Journal of Labor \& Society, 21(4), 533-560.

https://doi.org/10.1111/wusa.12366

Amazon Employees for Climate Justice. (2020, May 26). How Amazon's Emissions are Hurting Communities of Color. Medium.

https://amazonemployees4climatejustice.medium.com/environmental-justice-and-amaz ons-carbon-footprint-9e10fab21138

Amazon Sustainability. (n.d.). The Climate Pledge. Amazon Sustainability. Retrieved April 2, 2021, from https://sustainability.aboutamazon.com/about/the-climate-pledge

Crawford, K. (2021). Atlas of Al: Power, Politics, and the Planetary Costs of Artificial Intelligence. Yale University Press.

Dubal, V. B. (2020). A Brief History of the Gig (SSRN Scholarly Paper ID 3649694). Social Science Research Network. https://papers.ssrn.com/abstract=3649694

Suggested Citation (APA): Solomun, S. ${ }^{*}$ \& Bergmann, R. ${ }^{*}$ (2021, October). Diesel Death Zones in the Amazon Empire: Environmental Justice and Algorithmically Mediated Work. Paper presented at AolR 2021: The 22nd Annual Conference of the Association of Internet Researchers. Virtual Event: AolR. Retrieved from http://spir.aoir.org. 
Grist \& Marguerite Casey Foundation. (2020, January 10). Seeking environmental justice in California's "diesel death zones." Grist.

https://grist.org/sponsored/seeking-environmental-justice-in-californias-diesel-death-zon es

Kneese, T. (n.d.). Silicon Valley Uncovered: Race, Gender, Class syllabus (Davies Forum, pp. 1-18). University of San Francisco. Retrieved February 20, 2021, from https://www.academia.edu/38291146/Silicon_Valley_Uncovered_Race_Gender_Class_ syllabus

Morello-Frosch, R., Pastor, M., \& Sadd, J. (2001). Environmental Justice and Southern California's "Riskscape": The Distribution of Air Toxics Exposures and Health Risks among Diverse Communities. Urban Affairs Review, 36(4), 551-578.

https://doi.org/10.1177/10780870122184993

Parks, L., \& Starosielski, N. (2015). Signal Traffic: Critical Studies of Media Infrastructures. University of Illinois Press.

Roose, K. (2018, April 25). Workers of Silicon Valley, It's Time to Organize. The New York Times. https://www.nytimes.com/2018/04/25/technology/tech-workers-change.html

Sarathy, B. (2013). Legacies of Environmental Justice in Inland Southern California. Race, Gender \& Class, 20(3/4), 254-268.

Schlosberg, D., Rickards, L., \& Byrne, J. (2017). Environmental justice and attachment to place. In R. Holifield, J. Chakraborty, \& G. Walker, The Routledge Handbook of Environmental Justice (1st ed., pp. 591-602). Routledge.

https://doi.org/10.4324/9781315678986-47

Srnicek, N. (2016). Platform Capitalism. Wiley and sons. https://www.wiley.com/en-us/Platform+Capitalism-p-9781509504862

Tuana. (2019). Climate Apartheid: The Forgetting of Race in the Anthropocene. Critical Philosophy of Race, 7(1), 1. https://doi.org/10.5325/critphilrace.7.1.0001

Suggested Citation (APA): Solomun, S. * Bergmann, R. * (2021, October). Diesel Death Zones in the Amazon Empire: Environmental Justice and Algorithmically Mediated Work. Paper presented at AolR 2021: The 22nd Annual Conference of the Association of Internet Researchers. Virtual Event: AolR. Retrieved from http://spir.aoir.org. 